\title{
Does the Risk of Managerial Entrenchment Affect CEO Dismissal in Family SMEs?
}

\author{
Jonathan Bauweraerts ${ }^{1} \&$ Olivier Colot $^{1}$ \\ ${ }^{1}$ Warocqué School of Economics and Management, University of Mons, Mons, Belgium \\ Correspondence: Jonathan Bauweraerts, Warocqué School of Economics and Management, University of Mons, \\ Place Warocqué, 17, 7000, Mons, Belgium. Tel: 32-65-37-32-76. E-mail: jonathan.bauweraerts@umons.ac.be
}

Received: June 25, 2015

Accepted: September 8, 2015

Online Published: September 25, 2015

doi:10.5539/ibr.v8n10p41

URL: http://dx.doi.org/10.5539/ibr.v8n10p41

\begin{abstract}
The aim of this study is to identify the determinants of CEO dismissal in Belgian family SMEs. Based on a survey launched to 2.000 SMEs, 102 CEO dismissals were identified as well as other relevant features related to the family character of the firm. Logistic regressions have been used to explain CEO dismissal by several variables related to governance. The results indicate a significant influence of CEO attributes such as age and tenure on CEO dismissal. Also, firm age has been shown to enhance CEO dismissal. The other governance variables do not lead to significant findings. Taken together, these results suggest that specific risks of managerial entrenchment can explain CEO turnover in the context of family SMEs.
\end{abstract}

Keywords: CEO dismissal, family firms, corporate governance, managerial entrenchment

\section{Introduction}

This article investigates the impact of the risk of managerial entrenchment on the likelihood of CEO dismissal in the context of family SMEs. Prior research has mainly focused on listed family firms in Anglo-Saxon countries where ownership dispersion is high and managerial control is inefficient. As a result, the findings are difficultly generalizable to other contexts. In this study, we try to offer a more nuanced view of managerial entrenchment by focusing on Belgian family SMEs. This approach appears relevant for several reasons. First, the Belgian market has not received considerable attention from the literature (Voordeckers et al., 2007). Exploring managerial entrenchment on this market is particularly interesting as two governance models overlap: the Germano-Nippon model in the northern part of Belgium and a mixed model in the southern part. Moreover, entrenchment has often been considered as a negative phenomenon after Fama and Jensen's (1983) works that emphasize the maximization of managers' utility function at the expense of shareholders. By focusing on family SMEs, we investigate an organizational context where the alignment of interests between family owners and managers is more likely to be observed. By so doing, our study offers a contribution to the academic literature which urges scholars to contextualize governance research in the family business field (Nordqvist et al., 2014). Furthermore, we try to link different features of managerial entrenchment with CEO dismissal in order to determine whether entrenchment increases the likelihood that top executives keep their position in these organizations. By so doing, we offer a more nuanced view of managerial entrenchment which has been claimed to lead to inefficient decision-making processes (Bauweraerts \& Colot, 2014).

\subsection{Agency Theory and Managerial Entrenchment in Family Firms}

Agency theory analyses the conflicts that can occur between owners and managers, each of these stakeholders trying to maximize his/her utility function. According to the classical Anglo-Saxon view, managers have a long term vision of the company because of the contractual relation that binds them to the firm. Their objectives are to maintain their power in the organization and to maximize their compensation. In contrast, shareholders have a short term vision of the company as they want to maximize the return on investment the fastest possible. However, this conceptual framework remains general. Accordingly, the underlying hypotheses can drastically change depending on the context in which the firm evolves.

This area of research has been developed by Shleifer and Vishny (1989) and by Paquerot (1996) for the French market. The latter puts into perspective three phases during the entrenchment process: A valorization phase, a control-reducing phase and a consumption phase. This classical and rectilinear process supposes that managers 
use all flaws in the governance structure to extend their discretionary space and their managerial latitude in order to maximize their personal consumption. In that sense, Pigé (1998) showed that managerial entrenchment enables managers to free themselves from the supervision of the board of directors and the shareholders. This situation offers them a higher degree of freedom to take decisions and greater job security. However, do managers really adopt opportunistic behaviors? Two main streams are contradictory (Kesten, 2010). On the one hand, the dark side of managerial entrenchment indicates that managers pursue strategies and circumvent control mechanisms in order to extend their discretionary space and to divert resources at the expense of stakeholders. On the other hand, stewardship theory explains that managers would be trustworthy servants devoted to the interests of all stakeholders (Maati, 1999). According to this view, stakeholders have to encourage them in their actions to create value. In consequence, the bright side of managerial entrenchment would lead to organizational effectiveness (Charreaux, 1997). While several scholars empirically showed that managerial entrenchment has a negative impact on shareholders' wealth (Bedchuck et al., 2009; Gompers et al., 2010), Kesten (2010) reported that the dark side of managerial entrenchment tends to disappear since the 2007 financial crisis. He observed that the companies with relatively high degrees of managerial entrenchment outperform those with a lower degree of entrenchment. In addition, Schulze et al. (2001) demonstrated the importance of considering agency problems within family SMEs. They suggest that family firms could also suffer from opportunistic behaviors from family owners. Especially, additional costs resulting from altruistic attitudes can replace the classical agency costs between owners and managers. Moreover, they affirm that agency problems can not be easily solved through economic incentives since family members are already the residual owners of the company. Accordingly, family firms often face altruism problems that take the form of self-control problems that threaten the family and firm wealth (Schulze et al., 2003). In sum, managerial entrenchment as well as altruism and shared values can constitute an impediment to organizational effectiveness in family SMEs (Bauweraerts \& Colot, 2012).

\subsection{What are the Risks of Managerial Entrenchment in Family Firms?}

Managerial entrenchment takes two forms in family firms. Indeed, it could exist an entrenchment of the family owner-manager, but also a family entrenchment that exerts an influence after the retirement of the incumbent CEO (Allouche \& Amann, 2002). In that vein, several scholars argue that the entrepreneurial spirit is difficult to be passed onto the next generations (Jaskiewicz et al., 2015). As such, it would be easier for family descendants to create value through the use of their influence by extracting the company wealth rather than engaging in innovation. Following the same line, Allouche and Amann (2002) reported that the dark side of family entrenchment is more important when the proportion of shares held by family managers increases. In that situation, controlling family managers becomes complicated because of the nature of the family relationships which are likely to induce a bias regarding the competences of the family manager. Thus, the question is to determine the circumstances that create the conditions for the bright side (Castenias \& Helfat, 1991; Charreaux, 1997; Anderson \& Reeb, 2003; Isako \& Weisskopf, 2009) and the dark side (Morck et al., 1988; Shleiffer \& Vishny, 1989; Gallo \& Vilaseca, 1996; Schulze et al., 2001; Gomez-Mejia et al., 2001) to emerge.

Several studies have investigated the risks of family entrenchment and how it affects family firm performance and sustainability. Targeting family firms listed on the Fortune 500, Villalonga and Amit (2004) showed that family ownership is positively related to performance provided that the founder is also the CEO or the chairman of the board, agency problems only occurring at the second generation. Andres (2008) underlined that family firms display higher levels of performance when the family is actively involved in the top management team and/or the board of directors. Isako and Weisskopf (2009) brought evidence that family firms led by a descendent CEO who is also the chairman of the board display superior market and accounting performance.

However, Miller et al. (2007) revealed that the results obtained with large companies do not necessarily apply to smaller firms. They argue that family firms do not systematically outperform their nonfamily peers, which would explain the presence of nonfamily firms on the market. In that sense, Kowalewski et al. (2010) showed a neutral effect of family ownership on ROA over the period 1996-2004. They also find that having a family member as $\mathrm{CEO}$ and/or chairman of the board does not significantly affect family firm performance. Considering the Asian market, Peng and Jiang (2006) indicated that the influence of family entrenchment on performance depends on market regulations and institutional constraints.

Hillier and Mac Colgan (2005) highlights that, in comparison to nonfamily managers, family executives are less likely to be dismissed in case of poor performance on the London Stock Exchange. These results tend to indicate that the overlap of ownership and management stimulates altruistic and self-serving behaviors, which seems to confirm the dark side of family entrenchment (Giovannini, 2010; Kowalewski et al., 2010). Furthermore, other studies reveal a negative impact of family entrenchment on family firm performance. Chang and Zhang (2010) showed that family entrenchment (measured by a six-item scale) negatively affects Tobin $\mathrm{Q}$ on the American stock 
exchange over the period 1990-2007. In the same vein, Surroca and Tribo (2008) found that family entrenchment is detrimental to firm financial performance while the opposite for social activities that nurture the family socio-emotional wealth.

Based on the abovementioned studies, we observe that managerial entrenchment in family firms has mainly been investigated in the context of listed companies. The findings are relatively contrasted and sometimes contradictory. Consequently, it is impossible to have a unique vision about the impact of managerial entrenchment within family firms. This lack of homogeneity in the results and the prior focus on listed firms led us to explore both sides of family entrenchment in family SMEs.

A common assumption that could be made about managerial entrenchment in family SMEs is that it would naturally be stronger. Indeed, the ownership structure of family SMEs is characterized by concentrated ownership in the hands of the family and the presence of external investors is rather rare. Moreover, SMEs are not obliged to disclose information related to the compliance with corporate governance principles. Due to this opacity, the market for corporate control has a lower impact on the governance structure of family SMEs (Lubatkin et al., 2005). As a result, the likelihood that family managers are entrenched would be higher in this type of organization. Thus, family SMEs would represent an appropriate setting to explore managerial entrenchment: If managerial entrenchment is as negative as predicted by the classical theory, family SMEs should, on average, underperform their nonfamily peers.

Several arguments can explain this negative view of managerial entrenchment. First, family managers are more inclined to pursue the family agenda and to perpetuate the family legacy across generations (Berrone et al., 2012), which makes family managers difficult to replace. As a consequence, family SMEs would be less reactive in managerial succession when performance is poor. Also, they often possess tacit knowledge which is difficult to transmit to other managers in order to ensure organizational effectiveness (Mousa \& Wales, 2013). Furthermore, corporate governance is often ineffective owing to the significant involvement of family members in governance bodies. For instance, family CEO often occupy the position of chairman and outside directors are rarely welcomed to seat on the board (Bammens et al., 2008). Consequently, family SMEs would have some difficulties to benefit from an effective control and intellectual resources from outsiders (Daily \& Schwenk, 1996).

Owing to the centrality of family managers in the entrenchment process within family SMEs, we mainly focus on their specific attributes. This perspective is in line with the theoretical development of Hambrick and Mason (1984) as well as Smith et al. (1994) who stressed the importance of managers' attributes to understand organizational effectiveness. Goll (2011) found empirical evidence for this conceptual framework by showing a direct relationship between managers' demographic characteristics and performance. These contributions clearly illustrate the contributive value of managers (through their attributes) to the value creation process and/or the reinforcement of their entrenchment. (Zenou, 2006).

In this study, the general assumption is that the risk of managerial entrenchment will prevail in family SMEs. However, it is not necessarily the dark side that will express, such that higher degree of managerial entrenchment will not necessarily lead to organizational inertia in terms of CEO turnover.

\subsection{Hypotheses Development}

This research focuses on family SMEs which are not obliged to disclose operational information over corporate governance. As a result, we focus on the following variables that are generally used to assess managerial entrenchment (Huybrechts et al., 2013; Bauweraerts \& Colot, 2014):

$\begin{array}{ll}- & \text { CEO age; } \\ - & \text { CEO tenure; } \\ - & \text { Family ownership; } \\ - & \text { CEO duality; } \\ - & \text { Firm age; } \\ - & \text { Number of managers. }\end{array}$

First, we are going to focus on CEO age and tenure which have been shown to be hardly dissociable. Although several studies point out the positive impact of CEO age and tenure on the value creation process (Hambrick \& Mason, 1984; Boeker, 1997), others challenge this linear causality model and suggest that the relationship between these CEO attributes and value creation is rather curvilinear (Paquerot, 1996; Hambrick \& Fukutomi, 1991). As such, CEO age and tenure will have a positive impact on performance until a certain threshold after which an increase in these variables becomes detrimental to organizational effectiveness. 
The positive linear relationship can be explained by several arguments. It can be argued that older CEOs are more likely to have built social ties with numerous stakeholders that offer a positive contribution to firm performance. Moreover, older and longer tenured CEOs often possess more experience, which would be very helpful to realize specific investments with positive returns. According to this perspective, CEO age and tenure could enhance the bright side of managerial entrenchment.

Beyond this positive view, an alternative vision can be proposed. Indeed, older and longer tenured CEOs can also stimulate the dark side of managerial entrenchment. Following Shleifer and Vishny's (1989) classical theory, it would be easier for older and longer tenured CEOs to circumvent governance controls, such that they can take specific decisions that other managers will not be able to implement correctly. At the same time, CEOs honor implicit contracts with internal stakeholders in order to extend their power in the firm to make them irreplaceable. In that sense, Brockman and Thistle (2009) reported that CEO tenure is positively related to his/her ownership stake in the firm and his/her compensation. These authors also claim that firm value tends to decrease when CEO tenure and age increase since it becomes more complicated to remove him/her from the decision-making process. It is harder to rule out the CEO as he/she builds his/her reputational capital over time and can benefit from internal and external support to keep his/her job (Finkelstein, 1992). In line with these studies, Basly (2006) found that firm sustainability can be altered by excessive conservatism and strong affective attachment, which is likely to be reinforced when CEO tenure and age increase. All these studies seem to indicate that older and longer tenured CEOs are less likely to be dismissed even if the firm underperforms its competitors. For these reasons, the following hypotheses are proposed:

\section{H1: CEO age is negatively related to the likelihood of CEO dismissal.}

H2: CEO tenure is negatively related to the likelihood of CEO dismissal.

Another important factor that could have an impact on the likelihood of CEO dismissal is the ownership stake in the hands of a family. Indeed, family owners are often more inclined to perpetuate the family legacy and are thus more inclined to maintain a family member at the helm of the company independently from economic considerations (Berrone et al., 2012). Also, family CEO often display a strong emotional attachment to the organization (Gomez-Mejia et al., 2007). As a result, they would be less inclined to leave his/her position. Yet, they possess specific knowledge about the business, which makes them particularly difficult to replace even if they exhibit poor performance (Mousa \& Wales, 2013). In sum, family owners would show a greater propensity to maintain a family CEO as it serves them to ensure that their socioemotional and economic needs are fulfilled (Naldi et al., 2013). For these reasons, the following hypothesis is posed:

H3: Family ownership is negatively related to the likelihood of CEO dismissal.

CEO can also possess an ownership stake in the firm. In that case, he would have greater power in the organization and he would benefit from a greater managerial latitude to take decisions. As such, control procedures are less effective and it is more likely that the CEO remains at the helm of company despite poor performance. Therefore, the following hypothesis is suggested:

H4: CEO duality is negatively related to the likelihood of CEO dismissal.

Firm age can also exerts an influence on the likelihood of CEO dismissal. As this variable is often correlated to CEO age, the same reasoning used to develop hypothesis 1 prevails. As such, we suggest:

H5: Firm age is negatively related to the likelihood of CEO dismissal.

As it was not possible to obtain operational information related to board composition and functioning, we consider the supervision of managers as a control mechanism. The number of managers in the top management team was used to assess monitoring. Theoretically, a greater proportion of managers would represent a higher degree of control of the CEO. However, in SMEs, managers are not numerous and it is not rare that other family managers with the same vision are involved in management. For these reasons, the following hypothesis is posed:

H6: The number of managers is negatively related to the likelihood of CEO dismissal.

Past performance is also likely to have an influence on CEO dismissal. Indeed, the classical theory would say that the absence of value creation for shareholders leads to CEO dismissal. However, in family SMEs, past performance would not have an impact on CEO dismissal as family owners are more concerned with the preservation of their sociaemotional wealth which includes the perpetuation of family leadership through CEO position (Gomez-Mejia et al., 2007). As such, past performance is less likely to exert a significant effect on CEO dismissal. Therefore, we hypothesize: 


\section{H7: Past ROE is not related to CEO dismissal in family SMEs.}

Finally, firm size is also considered in the model and is assessed by the number of employees. While it should have a positive effect on CEO dismissal in case of poor performance for listed firms since they benefit from the market for corporate control, the same is not true in SMEs. Indeed, external control from the market is inexistent for SMEs (Lubatkin et al., 2005). Therefore, larger firms would be a fertile field for managerial entrenchment since CEOs have a greater chance to develop implicit contracts within the organization, such that they can keep their position at the helm of the company. Thus, the following hypothesis is proposed:

H8: Firm size is negatively related to the likelihood of CEO dismissal.

\section{Methodology}

\subsection{Sampling Method}

This research focused on Belgian SMEs (with less than 100 employees) which often present a family nature. To be sure that the family essence was deeply anchored in the company, we collect data for firms created before December 31, 1999. The financial information was collected from the Belfirst database provided by Bureau Van Dijk. The information related to ownership and management structures were derived from a survey launched to 2,000 SMEs.

The survey allows us to gather 391 exploitable answers, which represents a response rate of $19.55 \%$. Besides, we also test the representativeness of our sample based on a three criteria: sector affiliation, geographical localization, and the number of employees. At a 5\% threshold, our results indicated that no difference was observed between the respondents and non-respondents.

To determine whether the SME can be defined as a family business, we consider that a firm was a family business if it fulfills the two following criteria:

- A family possess at least $50 \%$ of the shares.

- The majority of the top management team is family dominated.

This definition has the advantage of being clear and based on easily measurable criteria. Moreover, this family firm definition is frequently used in the recent literature (Anderson \& Reeb, 2003; Colot, 2010; Hirigoyen \& Poulain-Rehm, 2014). Based on this definition, 318 SMEs can be considered as family businesses, which represents $81.33 \%$ of our sample. This observation is line with prior research led in Belgium (Witterwhulghe et al., 1994; Jorissen et al., 2002).

From our survey, we also identified 159 CEO dismissals, 130 presenting a family character. As some companies did not provide all the information related to CEO dismissal (date and governance variables), we finally obtain a sample of 102 SMEs with a CEO dismissal. These 102 SMEs have been paired with 102 SMEs which did not experience CEO dismissal in the same period. Matched-pair analysis enables to isolate demographic features that often alter the results in comparative studies (Jorissen et al., 2002; Westhead \& Cowling, 1998).

To proceed to the pairing, the control sampling was determined as follows:

- Family or nonfamily SME.

- Sector affiliation (based on NACEBEL nomenclature for sector classification in Belgium).

- Firm size: Total asset cannot vary with more or less $20 \%$ (Note 1).

To carry out the matched-pair analysis, we took into account the family character of the firm. As such, we paired family SMEs where a CEO dismissal was observed with family SMEs where no CEO dismissal was identified in the same period. We replicated this procedure for nonfamily SMEs. 
Table 1. Descriptive statistics

\begin{tabular}{|c|c|c|c|c|c|c|c|}
\hline Variables & & Mean & Médian & Standard Deviation & $\operatorname{Max}$ & Min & $\%$ \\
\hline \multirow[t]{2}{*}{ CEO age } & SMEs with CEO dismissal & 59.15 & 61.00 & 9.25 & 79.00 & 28.00 & \\
\hline & SMEs without CEO dismissal & 43.56 & 42.00 & 8.89 & 68.00 & 23.00 & \\
\hline \multirow[t]{2}{*}{ CEO tenure } & SMEs with CEO dismissal & 18.20 & 18.00 & 11.09 & 49.00 & 0.00 & \\
\hline & SMEs without CEO dismissal & 12.90 & 12.00 & 7.63 & 36.00 & 0.00 & \\
\hline \multirow[t]{2}{*}{ Firm age } & SMEs with CEO dismissal & 30.02 & 21.00 & 29.20 & 127.00 & 1.00 & \\
\hline & SMEs without CEO dismissal & 13.04 & 12.00 & 7.55 & 36.00 & 1.00 & \\
\hline \multirow[t]{2}{*}{ Number of managers } & SMEs with CEO dismissal & 1.54 & 1.00 & 0.80 & 5.00 & 1.00 & \\
\hline & SMEs without CEO dismissal & 1.65 & 1.00 & 0.81 & 4.00 & 1.00 & \\
\hline \multirow[t]{2}{*}{ Number of employees } & SMEs with CEO dismissal & 7.17 & 5.00 & 6.01 & 39.00 & 2.00 & \\
\hline & SMEs without CEO dismissal & 7.90 & 5.00 & 7.47 & 39.00 & 1.00 & \\
\hline Past ROE (one-period & SMEs with CEO dismissal & 37.06 & 28.85 & 71.62 & 300.00 & -321.70 & \\
\hline Lagged) & SMEs without CEO dismissal & 40.83 & 30.20 & 57.86 & 391.26 & -85.71 & \\
\hline Past ROE (two-period & SMEs with CEO dismissal & 42.80 & 27.03 & 77.73 & 479.14 & -239.20 & \\
\hline Lagged) & SMEs without CEO dismissal & 50.59 & 40.92 & 50.48 & 398.97 & -5.51 & \\
\hline \multirow[t]{2}{*}{ CEO duality } & SMEs with CEO dismissal & & & & & & 98.03 \\
\hline & SMEs without CEO dismissal & & & & & & 98.03 \\
\hline \multirow[t]{2}{*}{ Family ownership } & SMEs with CEO dismissal & & & & & & 76.47 \\
\hline & SMEs without CEO dismissal & & & & & & 78.43 \\
\hline
\end{tabular}

Descriptive statistics are presented in Table 1. It compares SMEs with CEO dismissal and SMEs without CEO dismissal. We observed that SMEs where a CEO was dismissed were considerably older. Also, it seems that older and longer tenured CEOs are more likely to be dismissed. Furthermore, it also appears that SMEs without CEO dismissal present higher past ROE one year and two years before CEO replacement.

\subsection{Econometric Procedure}

To test the impact of managerial entrenchment on the likelihood for CEO to be dismissed, logistic regressions were used. This procedure supposes that the dependent variable is a dummy variable with the value of 1 if the CEO has been dismissed (102 observations) and 0 otherwise (102 observations). The independent variables are CEO age, CEO tenure (the number of years the CEO is in charge of the firm), Family ownership (the percentage of shares held by the family), Firm age (the number of years since the company creation), CEO duality (a dummy variable equaling 1 if the CEO is also owners, 0 otherwise), the number of managers, Past ROE (calculated as Cash-flow/Equity lagged with one period), Firm size (calculated as the natural logarithm of the number of employees). We checked for multicollinearity to avoid biases in our regressions. After controlling for this issue, we had to separate several independent variables in the models: CEO age, CEO tenure and Firm age. This explain the presence of three different models in the following section.

\section{Results and Interpretations}

Our hypotheses were tested using the SPSS software. It is important to note that this software enables to automatically test for heteroscedasticity concerns. The results are presented in Table, 2, 3 and 4.

Table 2. The CEO age model

\begin{tabular}{lllll}
\hline & Beta & Standard Deviation & T-stat & $P$-value \\
\hline Intercept & -0.838 & 0.284 & -2.948 & 0.004 \\
CEO age & 0.028 & 0.003 & 11.025 & 0.000 \\
CEO duality & 0.009 & 0.227 & 0.04 & 0.968 \\
Family ownership & -0.07 & 0.072 & -0.971 & 0.333 \\
Firm size (Ln) & -0.019 & 0.039 & -0.48 & 0.632 \\
Number of managers & -0.024 & 0.039 & -0.624 & 0.533 \\
Past ROE & 0.000 & 0.001 & -0.782 & 0.425 \\
$R^{2}$ & 0.446 & & & \\
Adjusted $R^{2}$ & 0.424 & & & \\
$F$-stat & 20.622 & & & \\
Sig. & 0.000 & & & \\
\hline
\end{tabular}


The first model presented in Table 2 shows that CEO age is positively related to the likelihood of CEO dismissal while the other independent variables do not exert a significant influence on the dependent variable. This observation contradicts hypothesis 1 according to which CEO age should reduce the likelihood of CEO dismissal due to his/her higher degree of entrenchment. An explanation for this could be that family owners want to ensure that the firm will be passed onto the next generation. As a consequence, they would prefer to change the CEO when he becomes older as he/she is more likely to rely on path-dependent strategies that increase the risk of failure and bankruptcy of the firm (Lubinsky, 2011).

Table 3. The CEO tenure model

\begin{tabular}{lllll}
\hline & Beta & Standard Deviation & T-stat & P-value \\
\hline Intercept & .414 & .298 & 1.389 & .167 \\
CEO-duality & -.037 & .252 & -.148 & .882 \\
Family ownership & -.042 & .094 & -.452 & .652 \\
Firm size (Ln) & -.090 & .053 & -1.694 & .093 \\
Number of managers & .012 & .050 & .240 & .811 \\
Past ROE & .000 & .001 & .215 & .830 \\
CEO tenure & .018 & .004 & 4.313 & .000 \\
$R^{2}$ & 0.123 & & & \\
Adjusted $R^{2}$ & 0.086 & & & \\
F-stat & 3.286 & & & \\
Sig. & 0.005 & & & \\
\hline
\end{tabular}

In the second model reported in Table 3, CEO tenure is positively related to the likelihood of CEO dismissal. This result contradicts hypothesis 2 but is in line with the effect observed for CEO age in Table 2. Again, it seems that family owners prefer to dismiss longer tenured CEO to avoid the risks of entrenchment for the durability of the organization. Indeed, the lack of innovation that often characterized longer tenured CEO (Huybrechts et al., 2013) can jeopardize the future of the company, and thus socioemotional wealth preservation in the long term (Chrisman and Patel, 2012).

Table 4. The firm age model

\begin{tabular}{lllll}
\hline & Beta & Standard Deviation & T-stat & $P$-value \\
\hline Intercept & .594 & .282 & 2.107 & .037 \\
CEO duality & -.023 & .244 & -.096 & .924 \\
Family ownership & -.073 & .088 & -.831 & .407 \\
Firm size (Ln) & -.067 & .048 & -1.394 & .165 \\
Number of managers & -.026 & .049 & -.534 & .594 \\
Past ROE & .000 & .001 & .362 & .718 \\
Firm age & .008 & .002 & 5.179 & .000 \\
$R^{2}$ & 0.156 & & & \\
Adjusted $R^{2}$ & 0.123 & & & \\
F-stat & 4.740 & & & \\
Sig. & 0.000 & & & \\
\hline
\end{tabular}

The results reported in Table 4 reveal that Firm age is positively related to the likelihood of CEO dismissal. Even if this observation contradicts hypothesis 5 , it complements our previous findings regarding CEO age and tenure. It therefore seems that CEOs are more likely to be dismissed in older family SMEs. An explanation for this could be that family owners want to refresh the strategy of the organization in order to better fit with the constraints of the changing environment. By involving a new CEO in the decision-making process, family owners would operate in the interest of the company and the family by preserving the future economic and socioemotional wealth (Naldi et al., 2013).

Besides, we also observed that Firm size is negatively related to the likelihood of CEO dismissal. However, this finding is only confirmed in Table 3 at a lower level of significance. For these reasons, we can say that hypothesis is partially supported. It also appears that past performance does not exert any influence on the 
likelihood of CEO dismissal. This result is in line with hypothesis 7 and tends to confirm that family owners have a greater inclination to privilege long term return on their investment rather than short-term payout terms (Lumpkin \& Brigham, 2011). As a consequence, they do not penalize CEOs for poor levels of shareholders' return. Besides, hypothesis 3, 4 and 6 are not supported. A summary of our findings is presented in Table 5 .

Table 5. Summary of the findings

\begin{tabular}{lll}
\hline Hypotheses & Findings \\
\hline H1 & CEO age is negatively related to the likelihood of CEO dismissal. & The opposite is supported \\
H2 & CEO tenure is negatively related to the likelihood of CEO dismissal. & The opposite is supported \\
H3 & Family ownership is negatively related to the likelihood of CEO dismissal. & Not supported \\
H4 & CEO duality is negatively related to the likelihood of CEO dismissal. & Not supported \\
H5 & Firm age is negatively related to the likelihood of CEO dismissal. & The opposite is supported \\
H6 & The number of managers is negatively related to the likelihood of CEO dismissal. & Not supported \\
H7 & Past ROE is not related to CEO dismissal in family SMEs. & Supported \\
H8 & Firm size is negatively related to the likelihood of CEO dismissal. & Partially supported \\
\hline
\end{tabular}

\section{Conclusion}

An important issue in the family business field is the consequences of managerial entrenchment. Prior research has mainly focused on performance outcomes in listed family firms to assess the implication of managerial entrenchment (e.g. Castenias \& Helfat, 1991; Charreaux, 1997; Anderson \& Reeb, 2003; Isako \& Weisskopf, 2009; Bauweraerts \& Colot, 2014). In this study, we focused on another aspect that has been overlooked in the literature: the impact of managerial entrenchment on CEO dismissal in family SMEs.

Our results indicate that the risk of entrenchment can have a positive impact on the likelihood of CEO dismissal. Indeed, CEO age and tenure as well as Firm age have been shown to enhance CEO dismissal. These results seem to suggest that family SMEs with higher levels of specific risk of managerial entrenchment (older and longer tenured CEO, older firm) are more likely to dismiss their CEOs. Therefore, it appears that family owners are conscious of the risks that managerial entrenchment can induce for the future of the company and the family wealth, which pushes them to react and to hire new executives.

Besides, this study offers two main contributions to the family business literature. First, we investigate an organizational context in which managerial entrenchment has been underexplored (Carney et al., 2015). Furthermore, by providing results that are contradictory to the main stream of research, we add to the debate on how the risk of managerial entrenchment affects CEO turnover in family SMEs.

However, this research also suffers from several limitations that must be acknowledged. First, we did not take into account the generational status of dismissed CEO as we did not possess the information about this attribute. As it was shown that adopting a generational perspective is important to increase our current understanding of managerial phenomenon in family SMEs (Cruz \& Nordqvist, 2012), future research should integrate this variable to find potential intergenerational differences. Also, our study focused on a specific institutional setting of continental Europe. Accordingly, it would be interesting to replicate our study in other national setting to determine whether our results are generalizable to other national, cultural and institutional contexts (Minkov \& Hofstede, 2011). Finally, we considered the individual effect of different variables to estimate the risk of managerial entrenchment. Therefore, future studies could use a scale to assess the global risk of managerial entrenchment in order to determine if a unidimensional approach of managerial entrenchment would be more appropriate.

Finally, by investigating the determinants of CEO dismissal in the context of family SMEs, we offer novel perspectives that, we hope, will foster the emergence of future research in the field.

\section{References}

Allouche, J., \& Amann, B. (2002). L'actionnaire dirigeant de l'entreprise familial. Revue Française de Gestion, 5(141), 109-130.

Anderson, R., \& Reeb, D. (2003). Founding family ownership and firm performance: Evidence from the S\&P 500. The Journal of Finance, 58(3), 1301-1327. http://dx.doi.org/10.1111/1540-6261.00567

Andres, C. (2008). Large shareholders and firm performance-An empirical examination of founding-family ownership. Journal of Corporate Finance, 14(4), 431-445. http://dx.doi.org/10.1016/j.jcorpfin.2008.05.003 
Bammens, Y., Voordeckers, W., \& Van Gils, A. (2008). Boards of directors in family firms: A generational perspective. Small Business Economics, 31(2), 163-180. http://dx.doi.org/10.1007/s11187-007-9087-5

Basly, S. (2006). Propriété, décision et stratégie de l'entreprise familiale: Une analyse théorique. CRISC 12 (Cahier de Recherche de l'ISC), Centre de Recherche du Groupe ISC Paris, p. 32.

Bauweraerts, J., \& Colot, O. (2012). La gestion de l'entreprise familiale: Entre performance et endettement. Editions universitaires européennes, 2012, p. 240.

Bauweraerts, J., \& Colot, O. (2014). Performance implications of manager entrenchment in family firms. Business and Economics Journal, 5(2), 1-5.

Bebchuk, L., Cohen, A., \& Ferrell, A. (2009). What matters in corporate governance? Review of Financial Studies, 22(2), 783-827. http://dx.doi.org/10.1093/rfs/hhn099

Berrone, P., Cruz, C., \& Gomez-Mejia, L. R. (2012). Socioemotional wealth in family firms theoretical dimensions, assessment approaches, and agenda for future research. Family Business Review, 25(3), 258-279. http://dx.doi.org/10.1177/0894486511435355

Boeker, W. (1997). Strategic Change: The Influence of Managerial Characteristics and Organizational Growth. The Academy of Management Journal. 40(1), 152-170. http://dx.doi.org/10.2307/257024

Brookman, J., \& Thistle, P. D. (2009). CEO Tenure, the Risk of Termination and Firm Value. Journal of Corporate Finance, 15, 331-344. http://dx.doi.org/10.1016/j.jcorpfin.2009.01.002

Carney, M., Van Essen, M., Gedajlovic, E. R., \& Heugens, P. P. (2015). What do we know about private family firms? A meta-analytical review. Entrepreneurship Theory \& Practice, 39(3), 513-544. http://dx.doi.org/10.1111/etap.12054

Castanias, R. P., \& Helfat, C. E. (1991), Managerial Resources and Rents, Journal of Management, 17(1), 155-171. http://dx.doi.org/10.1177/014920639101700110

Chang, X., \& Zhang, H. F. (2010). Managerial entrenchment and firm value: A dynamic perspective. http://dx.doi.org/10.2139/ssrn.1537079

Charreaux, P. (1997). Le gouvernement d'entreprise, Corporate Governance, théorie et faits. Economica, Paris, p. 539.

Chrisman, J. J., \& Patel, P. C. (2012). Variations in R\&D investments of family and nonfamily firms: Behavioral agency and myopic loss aversion perspectives. Academy of Management Journal, 55(4), 976-997. http://dx.doi.org/10.5465/amj.2011.0211

Colot, O. (2010). Préparation des PME familiales belges à la transmission et impact sur la performance. Revue Internationale PME, 22(2), 94-132.

Cruz, C., \& Nordqvist, M. (2012). Entrepreneurial orientation in family firms: A generational perspective. Small Business Economics, 38(1), 33-49. http://dx.doi.org/10.1007/s11187-010-9265-8

Daily, C. M., \& Schwenk, C. (1996). Chief Executive Officers, Top Management Teams, and Boards of Directors: Congruent or Countervailing Forces? Journal of Management, 22(2), 185-208. http://dx.doi.org/10.1177/014920639602200201

Fama, E. F., \& Jensen, M. C. (1983). Separation of ownership and control. Journal of Law and Economics, 26(2), 301-325. http://dx.doi.org/10.1086/467037

Finkelstein, S. (1992). Power in top management teams: Dimensions, measurement, and validation. Academy of Management Journal, 35(3), 505-538. http://dx.doi.org/10.2307/256485

Gallo, M. A., \& Vilaseca, A. (1996). Finance in family business. Family Business Review, 9(4), 387-401. http://dx.doi.org/10.1111/j.1741-6248.1996.00387.x

Giovannini, R. (2010). Corporate governance, family ownership and performance. Journal of Management \& Governance, 14(2), 145-166. http://dx.doi.org/10.1007/s10997-009-9093-x

Goll, I., Sambharya, R. B., \& Tucci, L. A. (2001). Top management team composition, corporate ideology, and firm performance. Management International Review, 41(2), 109-129.

Gomez-Mejía, L. R., Haynes, K. T., Núñez-Nickel, M., Jacobson, K. J., \& Moyano-Fuentes, J. (2007). Socioemotional wealth and business risks in family-controlled firms: Evidence from Spanish olive oil mills. Administrative Science Quarterly, 52(1), 106-137. 
Gomez-Mejia, L. R., Nunez-Nickel, M., \& Gutierrez, I. (2001). The role of family ties in agency contracts. Academy of Management Journal, 44(1), 81-95. http://dx.doi.org/10.2307/3069338

Gompers, P. A., Ishii, J., \& Metrick, A. (2010). Extreme Governance: An analysis of dual-class firms in the United States. The Review of Financial Studies, 23(3), 1051-1088. http://dx.doi.org/10.1093/rfs/hhp024

Hambrick, D. C., \& Mason, P. A. (1984). Upper Echelons: The organization as a reflection of its top managers. Academy of Management Review, 9(2), 193-206.

Hambrick, D. C., \& Fukutomi, G. D. S. (1991). The seasons of a ceo's tenure. Academy of Management Review, 9(2), 719-742.

Hillier, D., \& McColgan, P. (2009). Firm performance and managerial succession in family-managed firms. Journal of Business Finance \& Accounting, 36(3-4), 461-484. http://dx.doi.org/10.1111/j.1468-5957.2009.02138.x

Hirigoyen, G., \& Poulain-Rehm, T. (2014). The corporate social responsibility of family businesses: An International Approach. International Journal of Financial Studies, 2(3), 240-265. http://dx.doi.org/10.3390/ijfs2030240

Huybrechts, J., Voordeckers, W., \& Lybaert, N. (2013). Entrepreneurial risk taking of private family firms: The influence of a nonfamily CEO and the moderating effect of CEO tenure. Family Business Review, 26(2), 161-179. http://dx.doi.org/10.1177/0894486512469252

Isakov, D., \& Weisskopf, J. P. (2009). Family ownership, multiple blockholders and firm performance. Finance International Meeting AFFI-EUROFIDAI, p. 32. http://dx.doi.org/10.2139/ssrn.1484574

Jaskiewicz, P., Combs, J. G., \& Rau, S. B. (2015). Entrepreneurial legacy: Toward a theory of how some family firms nurture transgenerational entrepreneurship. Journal of Business Venturing, 30(1), 29-49. http://dx.doi.org/10.1016/j.jbusvent.2014.07.001

Jorissen, A., Laveren, E., Martens, R., \& Reheul, A. M. (2002). Differences between Family and nonfamily firms: The impact of different research samples with increasing elimination of demographic sample differences. Conference Proceedings, RENT XVI, 16th workshop, Nov. 21-22, Barcelona, Spain, Universitat Autònoma de Barcelona, p. 20.

Kesten, J. B. (2010). Managerial entrenchment and shareholder wealth revisited: Theory and evidence from a recessionary financial market. BYU Law Review, 5(4), 1609-1660. http://dx.doi.org/10.2139/ssrn.1555856

Kowalewski, O., Talavera, O., \& Stetsyuk, I. (2010). Influence of family involvement in management and ownership on firm performance: Evidence from Poland. Family Business Review, 23, 45-59. http://dx.doi.org/10.1177/0894486509355803

Lubatkin, M. H., Schulze, W. S., Ling, Y., \& Dino, R. N. (2005). The effects of parental altruism on the governance of family-managed firms. Journal of Organizational Behavior, 26(3), 313-330. http://dx.doi.org/10.1002/job.307

Lubinski, C. (2011). Path dependency and governance in German family firms. Business History Review, 85(4), 699-724. http://dx.doi.org/10.1017/S0007680511001164

Lumpkin, G. T., \& Brigham, K. H. (2011). Long-term orientation and intertemporal choice in family firms. $\begin{array}{llll}\text { Entrepreneurship Theory and } & \text { 1149-1169. }\end{array}$ http://dx.doi.org/10.1111/j.1540-6520.2011.00495.x

Maati, J. (1999). Le gouvernement d'entreprise. De Boeck Supérieur.

Miller, D., Le Breton-Miller, I., Lester, R. H., \& Cannella, A. A. (2007). Are family firms really superior performers? Journal of Corporate Finance, 13, 829-858. http://dx.doi.org/10.1016/j.jcorpfin.2007.03.004

Minkov, M., \& Hofstede, G. (2011). The evolution of Hofstede's doctrine. Cross Cultural Management: An International Journal, 18(1), 10-20. http://dx.doi.org/10.1108/13527601111104269

Morck, R., Shleifer, A., \& Vishny, R. W. (1988). Management ownership and market valuation: An empirical $\begin{array}{lllll}\text { analysis. Journal of } & \text { Financial }\end{array}$ http://dx.doi.org/10.1016/0304-405X(88)90048-7

Morck, R., \& Yeung, B. (2004). Family Control and the Rent-Seeking Society. Entrepreneurship Theory and Practice, 28(4), 391-409. http://dx.doi.org/10.1111/j.1540-6520.2004.00053.x

Mousa, F. T., \& Wales, W. (2012). Founder effectiveness in leveraging entrepreneurial orientation. Management 
Decision, 50(2), 305-324. http://dx.doi.org/10.1108/00251741211203588

Naldi, L., Cennamo, C., Corbetta, G., \& Gomez-Mejia, L. (2013). Preserving socioemotional wealth in family firms: Asset or liability? The moderating role of business context. Entrepreneurship Theory and Practice, 37(6), 1341-1360. http://dx.doi.org/10.1111/etap.12069

Nordqvist, M., Sharma, P., \& Chirico, F. (2014). Family firm heterogeneity and governance: A configuration approach. Journal of Small Business Management, 52(2), 192-209. http://dx.doi.org/10.1111/jsbm.12096

Paquerot, G. (1996). L'enracinement des dirigeants et ses effets. Revue Française de Gestion, 111, 212-225.

Peng, M. W., \& Jiang, Y. (2011). Family ownership and control in large firms: The good, the bad, the irrelevant. Asia Pacific Journal of Management, 28(1), 15-39. http://dx.doi.org/10.1007/s10490-010-9228-2

Pigé, B. (1998). Enracinement des dirigeants et richesse des actionnaires. Finance Contrôle Stratégie, 1(3), $131-158$.

Shleifer, A., \& Vishny, R. (1989). Management entrenchment: The case of manager-specific investments. Journal of Financial Economics, 25, 123-139. http://dx.doi.org/10.1016/0304-405X(89)90099-8

Schulze, W. S., Lubatkin, M. H., Dino, R. N., \& Buccholtz, A. K. (2001). Agency relationships in family firms: Theory and evidence. Organization Science, 12(2), 99-116. http://dx.doi.org/10.1287/orsc.12.2.99.10114

Schulze, W. S., Lubatkin, M. H., \& Dino R. N. (2003). Toward a theory of agency and altruism in family firms. Journal of Business Venturing, 18, 473-490. http://dx.doi.org/10.1016/S0883-9026(03)00054-5

Smith, K. G., Smith, K. A., Olian, J. D., Sims, H. P., O’Bannon, D. P., \& Scully, J. A. (1994). Top management team demography and process: The role of social integration and communication. Adminstrative Science Quarterly, 49(4), 693-706. http://dx.doi.org/10.2307/2393297

Surroca, J., \& Tribó, J. A. (2008). Managerial entrenchment and corporate social performance. Journal of Business Finance \& Accounting, 35(5\&6), 748-789. http://dx.doi.org/10.1111/j.1468-5957.2008.02090.x

Villalonga, B., \& Amit, R. (2006). How do family ownership, control, and management affect firm value? Journal of Financial Economics, 80, 385-417. http://dx.doi.org/10.1016/j.jfineco.2004.12.005

Voordeckers, W., Van Gils, A., \& Van den Heuvel, J. (2007). Board composition in small and medium-sized family firms. Journal of Small Business Management, 45(1), 137-156. http://dx.doi.org/10.1111/j.1540-627X.2007.00204.x

Westhead, P., \& Cowling, M. (1998). Family firm research: The need for a methodological rethink. Entrepreneurship, Theory and Practice, 23(1), 31-56.

Wtterwulghe, R., Janssen, F., Mertens, S., \& Olivier, F. (1994). Le financement de croissance des entreprises moyennes belges par le recours au capital à risqué. Louvain-La-Neuve, IAG.

Zenou, E. (2006). La contribution dirigeant à la création de valeur: au-delà de la discipline. Une analyse empirique sur le marché français. CEREN Working Papers, ESC Dijon, Bourgogne, 17, 4-18.

Zerni, M., Kallunki, J. P., \& Nilsson, H. (2010). The entrenchment problem, corporate governance mechanisms, and firm value. Contemporary Accounting Research, 27(4), 1169-1206. http://dx.doi.org/10.1111/j.1911-3846.2010.01043.x

\section{Note}

Note 1. When several firms corresponded to these criteria, the closest in terms of total asset was selected for the pairing.

\section{Copyrights}

Copyright for this article is retained by the author(s), with first publication rights granted to the journal.

This is an open-access article distributed under the terms and conditions of the Creative Commons Attribution license (http://creativecommons.org/licenses/by/3.0/). 